\title{
Linguistic Brilliance: Rule of Law with Chinese Characteristics
}

\author{
Hamish McCardle ${ }^{1,2}$ \\ ${ }^{1}$ New Zealand Police, Wellington, New Zealand \\ ${ }^{2}$ The People's Public Security University of China, Beijing, China \\ Email: Hamish.mccardle@police.govt.nz
}

How to cite this paper: McCardle, $\mathrm{H}$. (2019). Linguistic Brilliance: Rule of Law with Chinese Characteristics. Beijing Law Review, 10, 278-286.

https://doi.org/10.4236/blr.2019.102017

Received: November 9, 2018

Accepted: March 22, 2019

Published: March 25, 2019

Copyright (c) 2019 by author(s) and Scientific Research Publishing Inc. This work is licensed under the Creative Commons Attribution International License (CC BY 4.0).

http://creativecommons.org/licenses/by/4.0/

\begin{abstract}
Rule of law discourse has been excited in recent years with China's reemergence as a state with global influence and its own interpretation of rule of law; a socialist rule of law with Chinese characteristics. If rule of law is to become a main theme of China's socialist justice system building in the next ten-year period, then some of the changes will necessarily reach well beyond China's internal system, potentially internationally. In terms of China's approach, it is possible to understand that developments of rule of law are being made with due recognition of exactly how much implementation work is actually required to shift the country forward. China's progress towards a socialist rule of law with Chinese characteristics will almost certainly be slow, measured and most importantly completed on China's terms, not the West's terms.
\end{abstract}

\section{Keywords}

Rule of Law, Socialist Rule of Law, Rule of Law with Chinese Characteristics, China's Constitutional Development, China's Socialist Democracy

\section{Introduction}

"Oh, East is East and West is West, and never the twain shall meet, Till Earth and Sky stand presently at God's great Judgment Seat; But there is neither East nor West, Border, nor Breed, nor Birth, When two strong men stand face to face, though they come from the ends of the earth!"

The poem by Rudyard Kipling (Kipling, 1889), has little to do with law, but it neatly observes one important aspect of the world; that is in some respects there exists an international dialogue about the perceived differences between the East and the West. Kipling's wry observation in the final lines of the poem is that there is in fact no difference in people of the world, only a geographical point of 
view. This is also a recurring theme relevant to the evolution of rule of law in both a Chinese and Western context.

The famous saying in circles of justice is that "justice must not only be done, but must also be seen to be done" (Hewart, 1924). While the saying rolls of the tongue rather easily, the achievement of both actual justice and the perception of justice in the mind of the public have proved difficult to achieve over the years. Indeed for China's first unifying ruler of the Qin Dynasty (秦始皇), seeing justice done evenly to a prescribed tariff for each type of crime was a significant step forward in creating the formative Chinese state; but was what Emperor Qin achieved in 221BC an early form of rule of law, or simply the ruling of the law? And by strange coincidence, at a similar point in ancient history yet thousands of miles away in Greece, the philosopher Plato wrote of a state led by a benevolent monarch who could dispense fair justice with an even hand; but were Plato's musings a rule of law, or an imaginary state where fair minded rulers ruled the rules?

The attractiveness of rule of law is widely acknowledged, and it holds in that both the Chinese and Western view of rule of law there is agreement that a system of law is important to govern a nation's affairs, as opposed to arbitrary decisions by individual government officials or rulers. Greek philosopher Aristotle said that "The rule of law is preferable to that of any individual" (Aristotle, 350 $\mathrm{BCE}$ ), and while one might expect that something important said over two millennia ago would be, by now, fully understood and settled; yet the passage of time has served only to illustrate that the important concept of rule of law remains somewhat abstract, with its meaning varying in different countries and cultures at different periods of time. The term rule of law has also become popular in international and domestic politics, contributing a depth to the discussion, but also a lack of certainty as to what it means; ${ }^{1}$ and, while the concept of rule of law is ancient, the popularized term "rule of law" is relatively modern only taking its current shape from $1600 \mathrm{AD}$ onwards; ${ }^{2}$ on one hand offering altruistic benefits of equality and fairness, while on the other hand a complexity in application with high costs in achieving compliance which can present a challenge to those in authority. Nonetheless, most countries around the world adopt or are striving towards rule of law (World Justice Project, 2017-2018), and China is a good example because it is seeking a path of further development of rule of law, but with one special qualification; it will be a rule of law with Chinese characteristics.

While rule of law reform is recognized as challenging, and with results sometimes unclear, it is because of its universal appeal that it continues to be up-held

\footnotetext{
${ }^{1}$ A literature review of "rule of law" reveals hundreds of articles and books on the topic, as well as comparative reviews examining thick and thin views of rule of law, or substantive and positive views, or religious and non-religious views of rule of law. Rule of law texts are not confined to academia; political theory, journalistic musings and propaganda are all in play.

${ }^{2}$ Although the concept is ancient, the modern version of the term "rule of law" in legal writing is often attributed to Justice Coke, (1628), Petition of Right Act 1628. United Kingdom Law Collection, https://www.bl.uk/collection-items/the-petition-of-right.
} 
as a non-ideological solution that seemingly no-one is against (Carothers, 1998). The past fifty-years of academic writing on rule of law has seen the evolution of two general streams, using descriptions such as substantive or "thick" versions of rule of law, and formal or "thin" versions of rule of law (Peerenboom, 2002). So-called thin definitions are said to be more formalistic and similar to rule by law models with less emphasis on content. A thin approach uses rule of law as an instrument of government action (Tamanaha, 2004), and to rule the people by strict law is sometimes associated with the legalism style of governance as mooted by Han Fei (韩非) as adopted in the Qin Dynasty. On the other hand the substantive or thick versions of rule of law are advocated by groups such as the International Bar Association, and commonly associated with countries from a common law background. As with the Delhi Declaration, ${ }^{3}$ and the United Nations Statement, ${ }^{4}$ thick definitions propose a form of typological guidance to the features they feel should exist in a system of rule of law.

\section{Linguistic Brilliance, a Rule of Law with Chinese Characteristics: 中国特色的法治}

China's official position on the rule of law is sometimes felt to be ambiguous because occasionally the terms used are; rule by law, rule according to law, or governing the country according to law, along with other close variations. Legal scholars would agree the concepts of "rule of law", "rule by law" and "rule according to law" can be rather different (Winston, 2005; Green, 2008), which raises the question why modern Chinese leaders, who are renowned for their careful and deliberate use of language in formal speeches, sometimes appear to use the terms interchangeably; after all Article 5 of China's Constitution Law appears unequivocal (National People's Congress, 1982):

“The People's Republic of China governs the country according to law and makes it a socialist country under rule of law."

This article suggests the choice of official language is deliberately nuanced, and in keeping with the Chinese tradition of moving a big idea forward slowly and step-by-step. The brilliance of such careful language is a long-practiced art in Chinese leadership speech-making, and paves the way for actual understanding of the Chinese characteristics component of a socialist rule of law. In China's situation, steps towards a rule of law can be viewed through the lens of recent public statements of leaders. These observations attempt to better understand what modern Chinese officials mean when they talk of a "rule of law with Chinese characteristics", and then just as easily switch the discussion to the language of "comprehensively governing the country by law", or "governed by law".

\footnotetext{
${ }^{3}$ Refer here to the 1959 work of the International Commission of Jurists; A report of the International Commissioner of Jurists, New Delhi 1959 titled The Rule of Law in a Free Society. https://www.icj.org/wp-content/uploads/1959/01/Rule-of-law-in-a-free-society-conference-report-1 959-eng.pdf.

${ }^{4}$ Refer to the full text found in the United Nations 2015 catalogue: Rule of Law Index. http://www.un.org/en/ga/president/66/Issues/Rule\%20of\%20Law/ruleoflawindex.shtml.
} 
Fresh emphasis in China on discussion about rule of law has been bolstered in 2013 and 2014 during the plenary meetings of the Communist Party of China (CPC). ${ }^{5}$ Adding to the interest are that recent official speeches use the term "rule by law” (依法治国), and President Xi Jinping has created a slogan term to “comprehensively govern the nation according to law” (全面依法治国), as a main theme of the deepening reform in China. ${ }^{6}$

President Xi seems clear that whatever form of rule of law emerges, it will be uniquely Chinese in character. The president has made regular mentions of the need for China to more comprehensively develop rule of law, while underlining the importance of Constitution-centred governance and calling for better awareness of both China's constitution and the rule of law. He has even gone so far as to create a new national "Constitution Day", celebrated from 2014 onwards each December 4. China's new Constitution Day aims to promote a “constitutional spirit." President $\mathrm{Xi}$ is reported to say that the Constitution guarantees the socialist path with Chinese characteristics, and that the rule of law must be in harmony with the Constitution $(\mathrm{Hu}, 2014)$. This is significant as constitutional law in China settles within it the basic understanding that rights, with 22 references to rights within its articles, are protected and the government shall not act against a basic right without penalty.

Adding to the tempo of change in China is the State Council which has been examining opportunities to strengthen rule of law. A white paper on judicial reform published in 2012 refers to the rule of law as the goal of judicial reform nine times throughout the paper. In particular the white paper draws together both China's historical contribution to legal thought as well as opportunities to develop it further. The white paper makes it clear that China's socialist system of justice with Chinese characteristics is not about to change, but rather will be enhanced, and by doing so China will make a contribution to world betterment. This is interesting as often China's official positioning is primarily internally focused; so for the preface of the paper to include an outward facing international ambition is noteworthy. Some commentators may view the claim as political rhetoric, but given the comprehensive nature of the changes underway it may be considered as genuinely motivated, and an interesting change in position that reflects China's increasing confidence on the world stage. One might consider that if China can successfully improve its socialist judicial system (with Chinese characteristics), why would that system not be a suitable contribution for betterment of mankind in other states? The white paper is also interesting because of the strong hint the preface makes that China is not intending to implement a rule of law system as defined by anyone else, but rather implement the fundamental principle of rule of law. This might reasonably be considered as the basic

${ }^{5}$ Refer news excerpt from the Global Times. (2014).Rule of Law to dominate fourth plenary session, Xinhua English News. Published 2014-10-23 17:17:42. Yang. Y. (2014). Highlights of communiqué of 4th plenary session of CPC Central Committee, Xinhua English News. 2014-10-23 19, pg 31:05. ${ }^{6}$ As quoted in Xinhua English News. (2014) Xi's Four Comprehensives a strategic blueprint for China, Xinhua English News, 2015-02-25-22:44:22,

http://news.xinhuanet.com/english/china/2015-02/25/c_127517905.htm. 
model, or the solidly agreed foundations of rule of law; in other words likely a formal or thin interpretation of rule of law that builds on China's ancient legal thought drawing in Confucian morals to emphasise individual responsibility as well as legalism to underscore socialist equality.

\section{A Change with Big Implications}

So, if rule of law is to become a main theme of China's socialist justice system in the next ten-years, then some of the changes will necessarily reach well beyond the justice system itself. It may also include, in fact some would say it must include, the governing style of the CPC itself, as well as the application of the Chinese Constitution to enjoy unprecedented supremacy. President Xi seems to be paving the way for that expectation with the creation of the sloganised four comprehensives: Comprehensively build a moderately prosperous society (全面 建成小康社会), Comprehensively deepen reform (全面深化改革), Comprehensively govern the nation according to law (全面依法治国), and Comprehensively strictly govern the Party (全面从严治党). ${ }^{7}$

The socialist rule of law with Chinese characteristics phrase is of course not new, and builds on the longstanding rationale of legal system development in China; see for example the overarching "Socialist system of laws with Chinese characteristics” (中国特色社会主义法律体系) (State Council Information Office, 2011). Such a system is well described by the State Council in its foreword in 2011 as:

"Governing the country by law and building a socialist country under the rule of law is a fundamental principle for the Communist Party of China (CPC) to lead the people and effectively govern the country. We need to bring into being a socialist system of laws with Chinese characteristics so as to ensure there are laws to abide by for the carrying on of state affairs and social life; this is a precondition and foundation for us to implement the fundamental principle of the rule of law in all respects, and an institutional guarantee for China's development and progress."

This enthusiasm for rule of law may also link to the campaign against corruption. President Xi aims to remind officials of the CPC's core values for the continued rejuvenation of new China, and prevent corruption from causing public anger; together these aims seem to generally increase intolerance of corruption in China. Initiatives are many and range from the internationally recognised operations Fox Hunt and Skynet, ${ }^{8}$ to more domestic agendas such as the Central Committee deciding to make local courts more impartial and to penalise officials for telling judges what to decide (Supreme People's Court, 2015). And, in case everyday laws fail to have the desired effect, President $\mathrm{Xi}$ is deliberately linking

${ }^{7}$ As quoted in Xinhua. (2014). President Presents Four Comprehensives, China Daily News. Cover story and page 2 .

${ }^{8}$ For a good summary of the available reporting of the Ministry of Public Security's Operation Fox Hunt and the Central Commission for Discipline and Inspection's Operation Skynet, visit China Daily. (2017). China/Fox Hunt Special Focus Portal

http://www.chinadaily.com.cn/china/Fox-hunt.html. 
in the relevance of China's highest law of all: the Constitution. Officials will now have to swear loyalty to China's constitution, and this accompanied by the new "Constitution Day" with directions to schools to teach its importance, make it clear to all officials that no matter what they may think of ordinary laws and regulations, there is one big constitutional law they cannot ignore (South China Morning Post, 2014).

These changes may shift China's paramount law from its description as a working-level constitution to one of paramount importance. President Xi's initiative is good in at least two ways. Firstly, it will support the anti-corruption campaign by emphasising the rule of law, rather than just continuing to pick off flies and the odd tiger. Secondly, the constitution upholds political rights, guarantees freedom of speech, of the press, of assembly, of association and of religious belief. So by upholding the constitution so strongly, President $\mathrm{Xi}$ is opening the door to China's liberal leaning academics to test the constitution's ability to protect citizens more broadly than previous decades.

This leads to a proposition that Chinese scholars and leaders, having created a rule by law system with thin rule of law characteristics millennia ago, have been adapting the two approaches contemporaneously for the past 2000 or so years, and what we see today is not at all a new beginning for rule of law in China, but rather further steps along a rather long road. If that proposition can be imagined as correct, it could partly explain the interchangeable approach in modern political discourse when Chinese leaders refer to the rule of law, rule by law and rule according to law within the same speech. It might also assist to explain the narrative expressed in the Chinese Constitution Preamble which paints a picture of slow and steady progress (National People's Congress, 1982):

"... will continue to adhere to the people's democratic dictatorship and the socialist road, persevere in reform and opening to the outside world, steadily improve socialist institutions, develop the socialist market economy, develop socialist democracy, improve the socialist legal system and work hard and self-reliantly to modernize the country's industry, agriculture, national defence and science and technology step by step and promote the coordinated development of the material, political and spiritual civilizations, to turn China into a socialist country that is prosperous, powerful, democratic and culturally advanced."

Although steady and progressive steps towards rule of law are undoubtedly being made, and on a solid basis of a stable Chinese state, it might still be felt China has some distance to travel yet. By elevating the Constitution President Xi is confirming that the target really is rule of law enhancement. The Socialist Rule of Law with Chinese Characteristics is surely the next longstanding verse which might yet be judged as fundamental to China's future success, domestically and internationally.

\section{Conclusion}

China is genuinely deepening its own unique model of rule of law. The rule of 
law is already constitutionally enshrined and progress has been made in improving procedural fairness, the judiciary, and access to the law. But the Constitution itself is constrained by the political system in China, leading some observers to describe the Chinese Constitution as a working-level constitution and others to describe it as a caged constitution.

For China, the story is both ancient and recent. Ancient because of the clear and ongoing influences in modern China of Confucius, Hanfei, Mozi and Daoist thought from more than 2000 years ago. Recent because it was only as late as 1997 during the 15th National Congress of the CPC that it was stated, "We must remain committed to coordinating the advancement of both rule of law and reform and to ensuring rule of law and rule of virtue work in concert with one another. We must instill core socialist values into the development of the rule of law, and develop the rule of law to provide a guarantee for the country's reform, development, and stability."

China's judicial reform has received great attention from both Chinese and Western commentators, and the Chinese version of rule of law appears to show an interesting convergence of research between Chinese and overseas legal scholars. As pointed out by Grand Justice Liu of the Supreme People's Court in the opening session of the two sessions meeting in 2014, the Chinese court system is imbued with the principle of "judicial transparency" and, among other campaigns, has promoted the Guiding Cases system to a nationwide extent. Simultaneously, different levels of Chinese courts have engaged in the practice of judicial law making. While the issue of judge-made law remains controversial both in practice and in theory in China, it is a quiet step toward the unspoken goal of a form of judicial independence. Furthermore, as judicial and legal reforms in general are embedded in the narrative of a "socialist democracy with Chinese characteristics", scholars are asking what socialist democracy might mean, and how to apply the different notions of this concept to the developing legal systems (Chen, 2015).

The existing innovations in socialist rule of law have been increasingly encouraged by an emboldened President $\mathrm{Xi}$ who is publically encouraging judicial reform at the central level. In this sense, the field of judicial reform would seem to continue to be a key barometer for China's overall legal development and will likely attract much scholarly interest. Significant progress in expanding a crackdown on corruption, deepening reform, and lessening social injustice is all taking place in China, and public satisfaction has increased accordingly, along with public support for President Xi. The enthusiasm has even spun-off into popularized television shows, for example, In the Name of the People (人民的名义), ${ }^{10}$ which has genuinely grabbed China's domestic audience attention with huge

${ }^{9}$ Refer to reportage from China.Org. (2015) http://www.xinhuanet.com//english/china/2017-03/18/c_136138841_5.htm.

${ }^{10}$ For further information on the popular "In the Name of the People" anticorruption television series in China visit Hunan TV site. In the Name of the People, 2017 series in Chinese 人民的名义 https://www.mgtv.com/. 
followership and public discussion of the show's scripts. The range of new perspectives China is adopting should allow all people to see constant progress in China's rule of law; as NPC spokeswoman Fu Ying pointed out at a press conference on March 4, 2015 (Fu, 2015):

"China has had its socialist legal system with Chinese characteristics since 2010. It is an important achievement in China's effort to rule the country according to law."

Overall, weather one fully supports China's evolving rule of law, or dislikes it for not embracing more Western elements, there is an inescapable conclusion; that is China is reinventing rule of law on their own terms, and that may hold global impact. John Naisbitt writes in his China Megatrends forum that China is creating an entirely new social, economic and political system, that by balancing the top-down and bottom-up political orders China has created a unique "vertical democracy" different from the horizontal one of the West (Naisbitt \& Naisbitt, 2010); and that China will not only change the global economy but also challenge Western democracy with its own model in coming decades. While the US has a system of two party elections, China has multi-party consultation. Such differences originate from their varying civilisations, with respective strengths and shortcomings and may be inherently more attractive or relevant to other developing states than the generalised western model of government.

President $\mathrm{Xi}$, and $\mathrm{CPC}$ over recent decades, have promised to build China into a country under rule of law, and judicial reforms have been strengthened. Such measures have contributed to the advancement of China's rule of law, and building China into a country under rule of law is now an important topic of the NPC and CPPCC sessions. Importantly for the people of China, rule of law discourse is being progressed in a way that is appropriately understood in Chinese language and by Chinese. While for Western legal and political commentators, there are undoubted frustrations, and at times confusion, at the manner of translation from the Chinese language and the formal language of the leadership when presenting the socialist rule of law with Chinese characteristics; nevertheless these brilliant linguistics are well understood by Chinese who are the primary audience for these changes.

In terms of China's approach, it is possible to understand that changes in China are not always based on hard policy, but made with a pragmatic recognition of exactly how much implementation work is actually required to shift frontline organisations in a large country, such big state apparatus such as police, procurators, and the judiciary. Traditional Chinese wisdom might also be relevant here as the cautions of an old Chinese proverb points out; "an oil lamp becomes brighter after trimming, so too then the truth becomes clearer after being discussed" (灯不拨不亮, 理不辩不明); Highlighting that when facing a complicated problem, truth develops over time through the comparison of ideas. China's progress towards a socialist rule of law with Chinese characteristics will almost certainly be slow, measured and most importantly completed on Chinese terms, not the West's terms. 


\section{Conflicts of Interest}

The author declares no conflicts of interest regarding the publication of this paper.

\section{References}

Aristotle. (350BC). Politics, Book III

Carothers, T. (1998). The Rule of Law Revival. Foreign Affairs, 77, 95-106. http://www.unz.org/Pub/ForeignAffairs-1998mar-00095 https://doi.org/10.2307/20048791

Chen, Q. (2015). New Perspectives on Rule of Law in China. China Focus. http://www.chinausfocus.com/political-social-development/a-new-perspective-on-therule-of-law-in-china/

Green, L. (2008). Positivism and the Inseparability of Law and Morals. New York University Law Review, 83, 1035-1058.

Hewart, C. J. (1924). R v Sussex Justices, Ex parte McCarthy. [1924]. KB 256, [1923]. All ER Rep 233.

Hu, Q. (2014). Xi Marks Constitution Day. Global Times, 2014-12-04.

Kipling, R. (1889). The Ballard of East and West, Edmund Clarence Stedman, ed. (1833-1908). A Victorian Anthology.

Naisbitt, J., \& Naisbitt, D. (2010). China's Megatrends, The 8 Pillars of a New Society, Harper Collins.

National People's Congress. (1982). Constitution of the People's Republic of China, China. National People's Congress.

Peerenboom, R. (2002). China's Long March toward Rule of Law (pp. I-Vi). Cambridge: Cambridge University Press. https://doi.org/10.1017/CBO9780511493737

South China Morning Post. (2014). China Ratifies Constitution Day Holiday. SCMP News Web.

https://www.scmp.com/news/china/article/1629919/china-ratifies-constitution-day-hol iday-enhance-rule-law-campaign

State Council Information Office. (2011). The Socialist System of Laws with Chinese Characteristics. Information Office of the State Council of the People's Republic of China.

Tamanaha, B. (2004). On the Rule of Law: History, Politics, and Theory. Cambridge: Cambridge University Press. https://doi.org/10.1017/CBO9780511812378

Winston, K. (2005). The Internal Morality of Chinese Legalism. Singapore Journal of Legal Studies, 313-347. https://doi.org/10.2139/ssrn.757354

World Justice Project. (2017-2018). WJP World Justice Project Index 2017-2018. https://worldjusticeproject.org/our-work/wjp-rule-law-index/wjp-rule-law-index-2017 \%E2\%80\%932018 